\title{
Bitola 2005
}

\author{
By Ron Holloway
}

Spring 2006 Issue of KINEMA

\section{INTERNATIONAL FILM CAMERA FESTIVAL "MANAKI BROTHERS" IN BITOLA}

When you see packed houses for all the screenings at a film festival, you know that this will be an event to be remembered. So it was at the $26^{\text {th }}$ International Film Camera Festival "Manaki Brothers" in Bitola (20-25 September 2005) under festival director Tomi Salkovski and selector-programmer Blagoja "Dore" Kunevski. Indeed, this specialized festival honouring the cinematographer had every reason to celebrate. For, as every film historian worth his salt knows, the first film shot in the Balkans was by the Manaki Brothers. Back in 1905, shortly after Yanaki Manaki returned home to Bitola in Macedonia from London with a Film Camera 300 in the Bioscope series bought from the Charles Urban Trading Company, he teamed with his photographer brother Milton Manaki to film in nearby Audela (today Greece) their 114-year-old grandmother at her spinning-wheel. Of course, a Manaki heir was a welcomed guest at the opening night ceremonies, and a vote of thanks goes to the Macedonian Cinematheque in Skopje and Kodak for the restoration of Manaki Brothers prints dating back to the early years of the 20th century.

The 132-page festival catalogue - listing 12 entries in the Competition, 34 in the "Balkanika" Retrospective, 15 in the Shorts Program, 20 in the Student Competition, plus a special screening of a new Macedonian feature film - affirmed that this was the showcase festival of its distinguished history. The two competition juries for the International Competition and the Student Film Competition - were augmented at the last minute by an ad hoc International Critics Jury (not to be confused with the FIPRESCI Jury). Nearly all of the competition entries had been awarded at major international film festivals over the past few months. Some fifty applications for the Student Film Competition had to be turned down for lack of an appropriate time slot. Next year, it was reported, an additional jury for the Short Film Competition is planned. The "Balkanika" retrospective of awarded films from Macedonia, ex-Yugoslav republics, and neighbouring countries in the Balkans introduced young audiences in particular to key productions of the past.

The icing of the festival cake was cinematographer Vittorio Storaro, whose trio of Oscars - for Francis Ford Coppola's Apocalypse Now (USA, 1979), Warren Beatty's Reds (USA, 1981), and Bernardo Bertolucci's The Last Emperor (UK, 1987) - has made him a legend in his own time. Not only was the Italian master honoured with a Lifetime Achievement Award, in conjunction with a special screening of The Last Emperor on opening night, but he also agreed to serve as president of the International Jury. And he gave generously of his time to conduct one of his patented "Writing with Light" seminars, drawn for the most part from his publications on cinematography but also augmented by his own personal observations on filmmaking today. Wherever Vittorio Storaro turned up, crowds gathered. Whenever he spoke about the highlights of his varied career over the past forty years, failures as well as successes, his audience was captivated and motivated by the lessons learned.

"I don't know why cinematographers are generally overlooked by international juries at major festivals on award nights," he said at his press conference. "But it seems that after a jury has voted on the prizes for films, directors, and actors, then someone thinks of filling in a gap with an 'extra camera award' for a deserving film or filmland that had been bypassed in the initial voting." He also felt that the term "DoP - Director of Photography" was a misnomer. "This came about when Hollywood cameramen formed their own union. They then wanted to underscore their importance by adding 'director' to the spot on the credits. The correct title is 'cinematographer' - a term we all should be proud of, considering the integrity of the profession." And although he conceded that the motion picture art has passed through various stages of development - from silent films to the talkies, from black-and-white cinematography to colour - he felt nonetheless that "digital technology robs a film of its heart and soul." Strong words, but to be expected from a master of light and shadow.

Handed a special award by the Macedonian Minister of Culture for his "outstanding contribution to the cinema," Croatian cinematographer Tomislav Pinter looked back in an interview at a distinguished career as cinematographer for circa 100 films produced in this corner of Europe. Asked about his work with Orson 
Welles as cinematographer on his aborted adaptation of Shakespeare's The Merchant of Venice (1969), a Canadian-American TV production, he responded that "working with Welles was a revelation - he knew exactly where to place the camera and which optic or lens to use for a shot." He recounted how he was chosen by Orson Welles as cinematographer on The Merchant of Venice after he saw how efficiently Pinter had worked on Veljko Bulaji's The Bridge Over the River Neretva (Yugoslavia, 1969), in which Welles played the Chetnik leader Mihajlović. With Orson Welles playing Shylock in The Merchant of Venice, along side Charles Gray as Antonio and Irina Maleyeva as Jessica, the shooting in Venice took place under difficult circumstances. We had to rise at $3 \mathrm{am}$, prepare the camera take at $4 \mathrm{am}$ while waiting for Welles to finish his makeup, then shoot between 5am and 7am, after which the city would come to life." Pinter's collaboration with Welles lasted three weeks - "then the money ran out." As for the negative, it mysteriously disappeared, but a 40-minute stump of the film is said to exist. "Croatian actress Oja Kodar would probably know, as she was with Orson Welles at this time."

The Golden Camera 300 was awarded to Zhu Yang, cinematographer on Gu Changwei's Kong que (Peacock, China), "for the lyrical style and consequent use of composition and images, as well as his excellent balance between the story and images." The Silver Camera 300 was shared by Alain Marcoen, cinematographer on Jean-Pierre and Luc Dardenne's L'enfant( The Child, Belgium), and Gyula Pados, cinematographer on Lajos Koltai's Fateless (Hungary), "for the inventive approach in the cinematography and writing of the story in images." And the Bronze Camera 300 was awarded to Ryszard Lenczewski, cinematographer on Pawel Pawlikowski's My Summer of Love (UK), "for the melancholic and passionate atmosphere in the composition of light."

Another top festival winner was Christian Berger, cinematographer on Michael Haneke's Caché (Hidden, France-Austria), who received both the Audience Award and the International Critics Prize. As for the International Critics Jury, this ad hoc assembly of eight visiting international critics cited Christian Berger "for his masterful blending of digital technology with classical cinematography to elucidate the inner emotions and conflicting viewpoints of an intellectual torn between an ethical code and his conscience."

The Bitola 2005 festival closed with a special screening of a new Macedonian feature film running out-ofcompetition: Sergej Stanojkovski's Kontakt (Contact, Macedonia-Germany), starring Macedonian jury member Labina Mitevska and popular Belgrade actor Nikola Kojo in a poignant tale penned by Serb screenwriter Gordan Mihic about two outsiders trying to piece together their torn lives in a society afflicted by greed, intolerance, and corruption. Once again, it was Croatian cinematographer Tomislav Pinter who contributed to the production his masterful skills of lighting and imagery.

\section{References}

\section{AWARDS}

Film Camera

\section{Competition}

Golden Camera 300

SHU Yang, cinematographer on GU Changwei's Kong que (Peacock, China)

\section{Silver Camera 300 - ex aequo}

Alain Marcoen, cinematographer on Jean-Pierre and Luc Dardenne's L'enfant (The Child, Belgium)

Gyula Pados, cinematographer on Lajos Koltai's Fateless (Hungary)

\section{Bronze Camera 300}

Ryszard Lenczewski, cinematographer on Pawel Pawlikowski's My Summer of Love (UK)

\section{Special Award by Mosfilm}

Robert Rodriguez, cinematographer on Robert Rodriguez's Sin City (USA)

\section{International Critics Award}

Christian Berger, cinematographer on Michael Haneke's Caché (Hidden, France-Austria) 
Students Jury Award - Faculty of Dramatic Arts, Skopje

Shu Yang, cinematographer on Gu Changwei's Kong que (Peacock, China)

Audience Award

Christian Berger, cinematographer on Michael Haneke's Caché (Hidden, France-Austria)

Best Camera

Ozon Achiktan's Marlis (Poland) - cinematographer Maciej Sobieraj

Best Director

Dušan Gligorov's Posle dozhdya (After the Rain, Russia) - cinematographer Ekaterina Dubrovskaya

Kodak Award

Zlatko Kalenikov's Sekavanya (Memories, USA-Macedonia) - cinematographer Zlatko Kalenikov

Darjan Pejovski's 15 Sekundiy (15 Seconds, Macedonia) - cinematographer Gjorgji Klincharov

Lifetime Achievement Award

Cinematographer Vittorio Storaro (Italy)

Award for Outstanding Contribution to Cinema

Cinematographer Tomislav Pinter (Croatia)

Student Film Competition

Best Film

Axel Danielson's Sommarlek (Summer Clouds, Sweden) - cinematographers Marten Hard, Axel Danielson

\section{Author Information}

Ron HOLLOWAY (1933-2009) was an American critic, film historian, filmmaker and correspondent who adopted Europe as his home in the early fifties and spent much of his life in Berlin. He was an expert on the study of German cinema and against all odds produced, with his wife Dorothea, the journal German Film, keeping us up-to-date with the work of directors, producers and writers and the showing of German films around the world.

In 2007, Ron Holloway and his wife were awarded the Berlinale Camera Award. Ron also received the Bundesverdienstkreuz (German Cross of Merit), Polish Rings, Cannes Gold Medaille, the American Cinema Foundation Award, the Diploma for Support of Russian Cinema and an honorary award from the German Film Critics' Association.

Ron was also a valued contributor to Kinema for the past fifteen years. 